\title{
IDENTIFICATION OF WET AREAS IN FOREST BY USING LIDAR BASED DEM
}

\author{
Janis IVANOVS, Latvian State Forest Research Institute "Silava". Adress: 111 Rigas str., Salaspils, LV-2169 Latvia; \\ janis.ivanovs@silava.lv (corresponding author) \\ Irina SIETINA, Latvian State Forest Research Institute "Silava". Adress: 111 Rigas str., Salaspils, LV-2169 Latvia; \\ irina.sietina@silava.lv \\ Gints SPALVA, Latvian State Forest Research Institute "Silava". Adress: 111 Rigas str., Salaspils, LV-2169 Latvia; \\ gints.spalva@silava.lv
}

Water tends to flow and accumulate in response to topographical characteristics of local area and gravitational potential energy. Remote sensing data like LiDAR (Light detecting and ranging) or satellite data can be used to identify local depressions where wet areas may occur. The aim of this study was to evaluate methods that can be used to identify wet areas, to determine correlation between topography of the area and forest regeneration and to prepare proposals for forest management that could be usable in Latvia. Study area includes fertile forest land on wet mineral soils and drained mineral soils with planted spruce (Picea abies) and available LiDAR data. Map examples have been made to demonstrate methodology which allows to identify depressions with potentially hindered run-off. Fill sinks algorithm has shown best results in identifying wet areas and correlation with wet areas that were detected in field studies is $62 \%$. TWI index is not suitable for this study because of relatively flat area. Result of this study reveals that wet areas have significant effect on tree species. In depressions, despite the fact that there has been planted spruce, main species are birch (Betula pendula) and black alder (Alnus glutinosa). Wet areas have significant effect on tree height.

Keywords: Depressions, fill sink, GIS.

\section{INTRODUCTION}

Poorly drained and wet soils are challenge in forestry, agronomy and similar fields (McNabb et al, 2001). Wet areas are important for various habitats, biodiversity and for water exchange and chemical processes (Detenbeck et al, 1999), thereby it is important for sustainable forest management to know exact locations of those areas (Moore et al, 1991). Information about wet areas helps to improve land management and to avoid operational incidents like rutting and soil compaction (Curzon et al, 2013), and their as sociated environmental and financial costs (Christensen et al, 1996). Riparian buffers can be used to protect surface waters from harm by harvesting and have become the norm in freshwater ecosystemprotection in Northamerica (Richardson, 2012)

Surface topography is important for hydrological processes and different topographical indices are in use to describe spatial distribution of soil moisture. Groundwater flow often coincides with slope of the hill. Groundwater flow direction is important for soil forming processes (Burt et al, 1985; Zinko et al, 2005). Stream network extraction from DEM (digital elevation model) is common practice for surface water flow modelling, which in combination with Depth to-Water mapping can be used in determination of wet areas (Ågren, 2015).

Topographical wetness index (TWI) is developed by (Beven et al, 1979). It represents catchment topography by means of a topographic index, $\ln (\alpha / \tan \beta) ; \alpha$ is the area draining through a grid square per unit length of contour and tan $\beta$ is the average outflow gradient from the square. TWI can be used to describe spatial distribution of hydrological and chemical processes (Robson et al, 1992), biological processes (White et al, 1994), vegetation (Moore et al, 1993) and forest stand vitality (Holmgren, 1994).

Surface topography is also important for soil $\mathrm{pH}$ (Högberg et al, 1990). Soil moisture and $\mathrm{pH}$ are important indicators that affects spatial distribution and diversity of vascular plants in Nordic boreal forests (Sørensen et al, 2006; Zinko et al, 2005) in their study by using TWI explains 52\% of plant species diversity variation in forest stands with relatively high soil $\mathrm{pH}$ and $30 \%$ of variation in forest stands with relatively low soil pH. Geographic Information Systems (GIS) software has become important processing tool in several fields. Fill sinks is an algorithm that is often used in hydrological modelling to discern flow direction. Fill sinks algorithm 'fills' depressions in digital elevation model (DEM) 
to correctly calculate flow direction, otherwise streams would flow into depressions and never flow further (Jenkins et al, 2006). In this study to fill depressions we use method that is proposed by Wang and Liu, which uses concept of s pill elevation (Wang et al, 2006). After filling depressions in DEM and further processing data it is possible to get spatial information about depressions. Information about depressions is useful in managerial decision making processes.

Maps of wet areas are already in use in Sweden, where soil damage (rutting, soil compacting) by logging process is halved since methodology is transferred to practice. Information about wet areas is mostly used in heavy forest machinery routing. One of most successful commercial tools is software program Best Way, which is developed by Sweden forestry research institute Skogforsk (Johansson, 2015).

\section{MATERIALS AND METHODS}

\section{Sample plot empirical survey}

To verify modelled data, 30 sample plots have been made in young forest stands on wet mineral soils and drained mineral soils (Figure 1). Total area of 85 ha has been studied both in depressions and control points. Sample plots have been placed in depressions which are at least $250 \mathrm{~m}^{2}$ large and data about tree species, diameter and height were collected. Results were compared with existing database tree parameters. Empirically borders of depressions were tracked by plant species in ground vegetation. Only in 2 sample plots plant species that are common in wet areas were not det ected. Borders of depressions were tracked by using Garmin eTrex 30 GPS receiver.

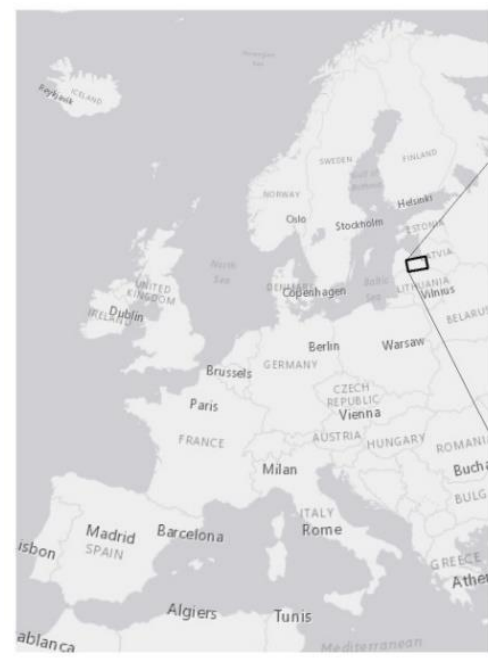

\section{Remote sensing}

Two algorithms were used to identify depressions in DEM's. DEM's were generated from LiDAR data with average ground point cloud density at least $4 \mathrm{p} / \mathrm{m}^{2}$. Raster cell size were $2 * 2$ meters. For TWI index algorithm to work correctly it is necessary to correct DEM with Fill sinks tool. After correcting DEM's, flow direction, flow accumulation and slope were calculated. TWI were calculated by formula 1 :

$$
\ln \left({ }^{\prime} F L O W A C C^{\prime} * 900 / \tan \left(' S L O P E^{\prime}\right)\right),
$$

Other approach was fill sinks method, where, filled (modified) DEM were subtracted from original DEM. In resulting raster, values that were below 0 indicated depressions with potentially hindered runoff. For this method to work correctly it is necessary that sample plot areas are not on edge areas of DEM, because algorithm may 'think' that runoff may happen over the edges of DEM. To avoid this problem, it is necessary to merge neighbouring raster mosaics. Before running this algorithm, it is advisable to check DEM for bridges, culverts, dams or similar objects, that in processing may block water runoff in places where it should not do it. If necessary, DEM should be corrected. After processing DEM, depressions were transformed to vector files and area and shape of them were calculated.

\section{RESULTS AND DISCUSSION}

\section{Comparison of forest inventory in depressions and control sample plots}

There is significant difference in results from survey and database in tree height and diameter, but not in growing stock. There is significant difference in tree (spruce) height between depression and control sample plots (Figure 2). Difference in tree species between depression and control sample plots are substantial - in depressions it's common that spruce is replaced by birch and black alder. Spruce population in depressions on average are $42 \%$ down comparing by control sample plots (Figure 3). 


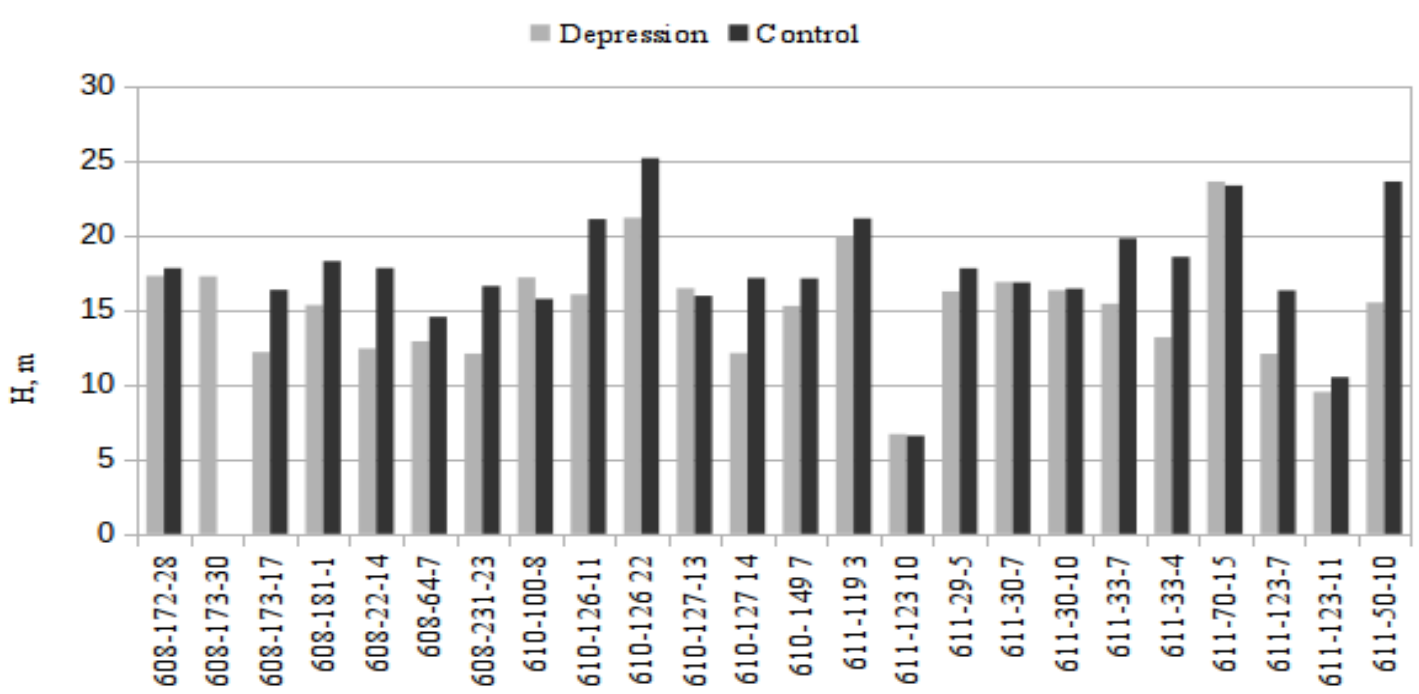

Figure 2. Differences in tree height between depression and control sample plots

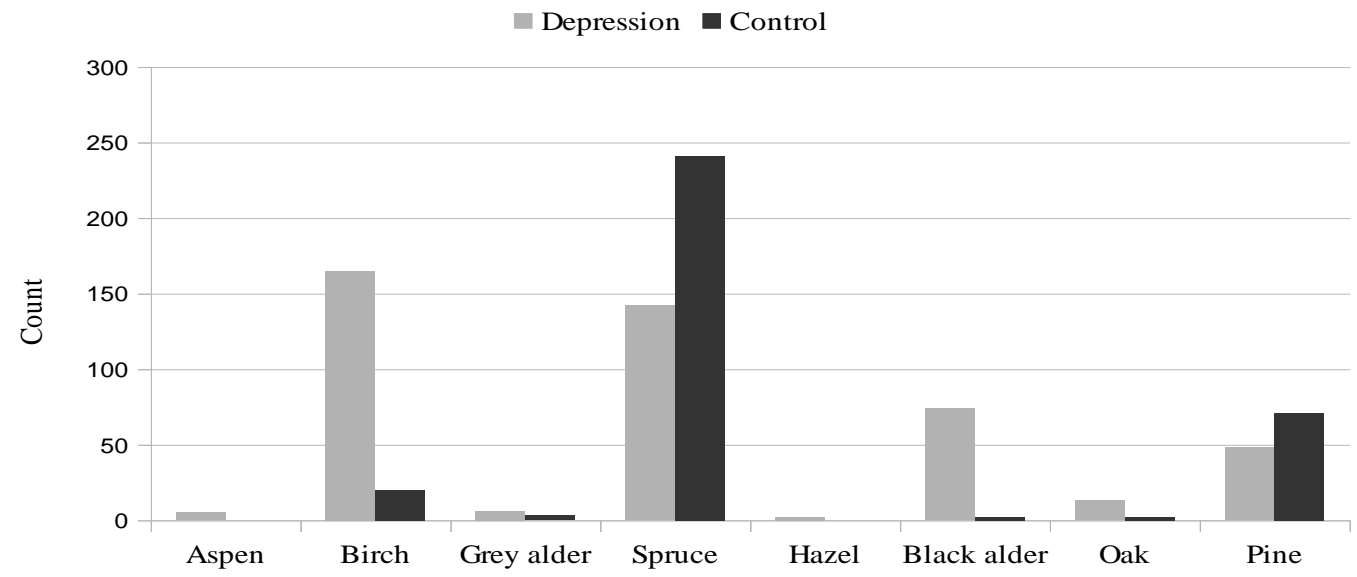

Figure 3. Common tree species in depression and control sample plots

\section{Analysis of remote sensing options in depression identification.}

Depression identification using DEM's made from LiDAR data is examined in different papers and is characterized as perspective. In this study, by processing LiDAR data, 29 depressions were selected and only 2 of them were not found in field works. By changing parameters of depression characteristics (area, depth) in processing and filtering data it is possible to get different depression characteristics. DEM data should be corrected to better represent natural water flow. Bridges, culverts and dams in LiDAR data are blocking modelled water flow, while in nature water may flow freely through these structures. Further study is needed to evaluate best parameters.

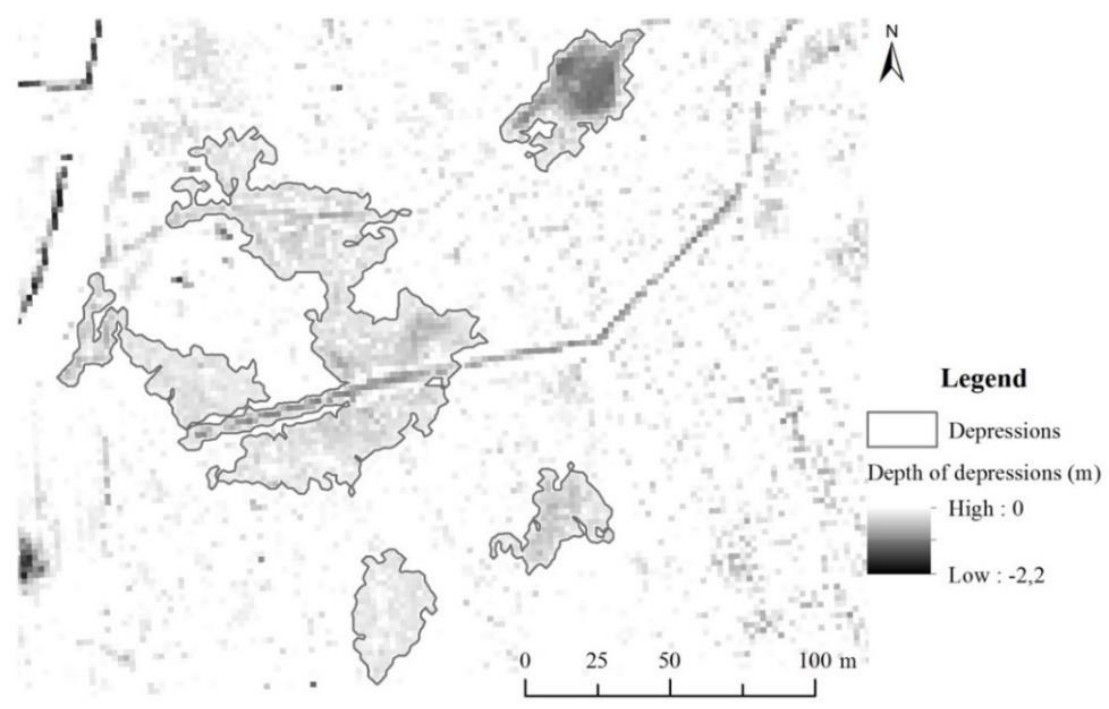

Figure 4. Example of map of wet areas 
Example of wet area data is shown in Figure 4. In this area are couple of large depressions with probably hindered water runoff. In forest management this data can help in decision making for drainage system development. To better understand local water flow characteristics, information about soil properties (granulometry, density, filtration etc.) is needed.

\section{Comparison of modelled and empirically detected depressions}

Depressions which are at least $500 \mathrm{~m}^{2}$ were modelled using Fill sinks algorithm. Minimal depth of depressions were selected as 0.05 and $0.02 \mathrm{~m}$. Results shows that modelled depressions with minimal depth of $0.05 \mathrm{~m}$ overlaps empirically surveyed depressions on average by $47 \%$ (a) (Figure 5). Depressions with minimal depth of $0.02 \mathrm{~m}$ overlaps empirically surveyed depressions on average by $62 \%$ (b). Soil texture and infiltration properties should be implemented in future studies in order to correctly determine borders of wet areas.

a)

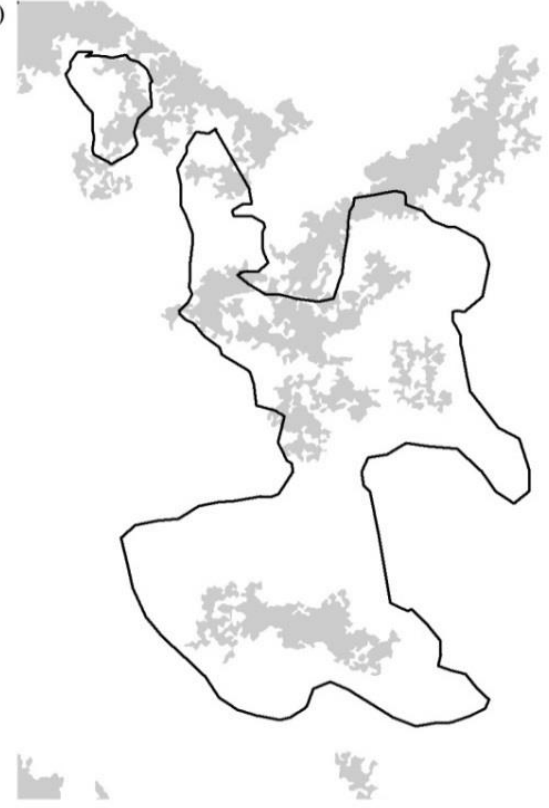

b)

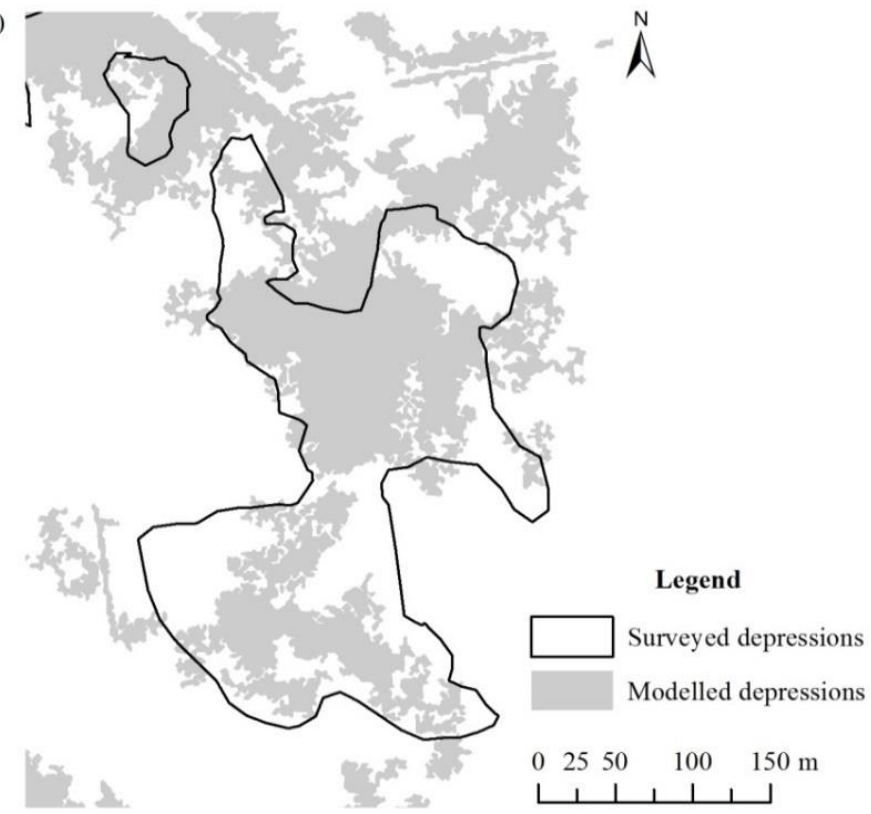

Figure 5. Comparison of depressions with different modelling parameters

Further studies are needed to evaluate different depression detection algorithms as well as capabilities of different remote sensing data. TWI index could not correctly detect depressions and potentially wet areas because of relatively flat area.

\section{CONCLUSIONS}

Detection of depressions using LiDAR data and already available algorithms is perspective and useful for management and planning of forestry activities. Results shows that there is significant differences in tree species and tree height in depressions and control plots. To take full advantage of options provided by LiDAR data, methods of data processing and analys is have to be improved. Different remote sensing data should be applied to characterize changes in tree species composition and soil moisture.

Field studies showed that there was large variability in modelling precision in configuration of wet areas. Information about soil characteristics should be implemented in future studies in order to understand rate of potential infiltration and water regime in depressions. It is important, because in different soil settings and climate conditions, depressions and riparian buffer zones may be in different shapes and some parts of depressions may by dry and trafficable.

To improve used methods, water flow and accumulation should be modelled, to better evaluate locations of water concentration. Information about water flow characteristics would be useful in drainage system planning.

\section{ACKNOWLEDGEMENTS}

The study is implemented within the scope of the Forest Sector Competence Center project No. 1.2.1.1/16/A/009.

\section{REFERENCES}

1. Ågren, A.M, Lidberg, W., Ring, E. 2015. Mapping Temporal Dynamics in a Forest Stream Network - Implications for Riparian Forest Management. Forests, Vol. 6, pp. 2982-3001. https://doi.org/10.3390/f6092982

2. Beven, K. J., Kirkby, M. J. 1979. A phy sically based, variable contributing area model of basin hy drology. Hydrological Sciences Bulletin, Vol. 24, Iss. 1, pp.43-69. https://doi.org/10.1080/02626667909491834

3. Burt, T. P., Butcher, D. P. 1985. Topographic controls of soil moisture distributions. Journal of Soil Science, 36(3), 469-486. https://doi.org/10.1111/j.1365-2389.1985.tb00351.x 
4. Christensen, N. L., Bartuska, A. M., Brown, J. H., Carpenter, S., D'Antonio, C., Francis, R. Woodmansee, R. G. 1996. The Report of the Ecological Society of America Committee on the Scientific Basis for Ecosystem Management. Ecological Applications, Vol. 6, Iss. 3, pp. 665-691. https://doi.org/10.2307/2269460

5. Curzon, M.T., D'Amato, A.W., Palik, B.J. (2013). Harvest residue removal and soil compaction impact forest productivity and recovery: Potencial implications for bioenergy harvests. Forest Ecology and Management, Vol. 329, pp. 99-107. https://doi.org/10.1016/i.foreco.2014.05.056

6. Detenbeck, N. E., Galatowitsch, S. M., Atkinson, J., Ball, H. 1999. Evaluating perturbations and developing restoration strategies for inland wetlands in the Great Lakes basin. Wetlands, Vol. 19, Iss. 4, pp. 789-820. https://doi.org/10.1007/BF03161785

7. Högberg, P., Johannisson, C., Nicklasson, H., Högbom, L. 1990. Shoot nitrate reductase activities of field-layer species in different forest ty pes. Scandinavian Journal of Forest Research, Vol. 5(1-4), pp. 449-456. https://doi.org/10.1080/02827589009382627

8. Holmgren, P. (1994). Topographic and geochemical influence on the forest site quality, with respect to Pinus sylvestris and Picea abies in Sweden. Scandinavian Journal of Forest Research, Vol. 9, Iss. 1-4, pp. 75-82. https://doi.org/10.1080/02827589409382815

9. Jenkins, D. G., Mccauley, L. A. 2006. GIS, SINKS, FILL, and Disappearing Wetlands : Unintended Consequences in Algorithm Development and Use. Proceedings of the 2006 ACM Symposium on Applied Computing, pp. 277-282. https://doi.org/10.1145/1141277.1141342

10. Johansson, S. 2015. Next Generation of Production Planning. Shortcuts, 1, 5.

11. McNabb, D. H., Startsev, A. D., Nguyen, H. 2001. Soil Wetness and Traffic Level Effects on Bulk Density and Air-Filled Porosity of Compacted Boreal Forest Soils. Soil Science Society of America Journal, Vol. 65(4), pp. $1238-1247$. https://doi.org/10.2136/sssaj2001.6541238x

12. Moore, I. D., Grayson, R. B., Ladson, A. R. 1991. Digital terrain modelling: A review of hydrological, geomorphological, and biological applications. Hydrological Processes, Vol. 5(1), pp.3-30. https://doi.org/10.1002/hyp.3360050103

13. Moore, I. D., Norton, T. W., Williams, J. E. (1993). Modelling environmental heterogeneity in forested landscapes. Journal of Hydrology, Vol. 150(2-4), pp. 717-747. https://doi.org/10.1016/0022-1694(93)90133-T

14. Richardson, J.S., Naiman, R.J., Bisson, P.A. 2012. How did fixed-width buffers become standard practice for protecting freshwaters and their riparian areas from forest harvest practices? Freswater Science, Vol. 31(1), pp. 232-238. https://doi.org/10.1899/11-031.1

15. Robson, A., Beven, K., Neal, C. 1992. Towards identify ing sources of subsurface flow: A comparison of components identified by a physically based runoff model and those determined by chemical mixing techniques. Hydrological Processes, Vol. 6(2), pp. 199-214. https://doi.org/10.1002/hyp.3360060208

16. Sørensen, R., Zinko, U., Seibert, J. 2006. On the calculation of the topographic wetness index: evaluation of different methods based on field observations, 101-112.

17. Wang, L., Liu, H. 2006. An efficient method for identifying and filling surface depressions in digital elevation models for hydrologic analysis and modelling. International Journal of Geographical Information Science, 20(2), 193-213. https://doi.org/10.1080/13658810500433453

18. White, J. D., Running, S. W. 1994. Testing scale dependent assumptions in regional ecosystem simulations. Journal of Vegetation Science, Vol. 5(5), pp.687-702. https://doi.org/10.2307/3235883

19. Zinko, U., Seibert, J., Dynesius, M., Nilsson, C. (2005). Plant species numbers predicted by a topography -based groundwater flow index. Ecosystems, Vol. 8(4), pp.430-441. https://doi.org/10.1007/s10021-003-0125-0 